\title{
Hedging Your Bets? - An Overview of the Legal Aspects of Hedge Funds
}

\author{
Zsolt BuJTÁR* \\ ANDRÁS KECSKÉs**
}

\begin{abstract}
Hedge funds are a controversial element of the global financial system, as their activities can affect countries' economies to a great degree. Therefore, it is important to gain insight into their operation. The aim of the article is to give an overview of some legal aspects of hedge funds and starts with a definition of hedge funds, whilst also giving a historical overview of their genesis. The following parts outline the legal framework for hedge funds in the USA and the European Union. The conclusion is that regulation for hedge funds are flexible in spite of the reforms in the legal framework after the events of the financial crisis, which still makes them an attractive proposition for the 'high society' of investors.
\end{abstract}

Keywords: hedge fund, financial market, regulation, financial crisis, investment

\section{INTRODUCTION}

Hedge funds are a controversial element of today's global financial system and the word is amiliar across the world of institutional investors through the studios of Hollywood as well as within the context of small investors' modest rate of return. The influence of hedge funds does not come across as a surprise, since their history of operation marked with tremendous profits and dramatic losses. For long periods of time, the promised risky success was not available for small-scale investors e.g. in the United States it was not possible to invest in hedge funds below USD 1,000,000 (USD 250,000 later on). Nowadays, it seems rather reasonable to explore the characteristics of hedge funds in a more in-depth manner as the base rates of central banks ${ }^{1}$ forecast only a minor increase in certain aspects. However, the task at hand is far from being simple, as the contextual definition of hedge fund already contains certain discrepancies.

\section{CONTEXTUAL DEFINITION OF HEDGE FUNDS}

Defining hedge fund is by no means easy, especially with taking into consideration that most definitions created by the legal literature use a negative approach in order to determine the concept. The word hedge fund originates from the expression 'hedged fund', which indicates a financial fund covering risks with certain investment techniques and instruments. Covering financial risks means taking a reverse position with the same volume (speculating to reverse market movements) contrary to the one taken previously with regards to a certain financial asset (investment instrument).

* Assistant Lecturer, University of Pécs, Faculty of Law bujtar.zsolt@ajk.pte.hu.

** Associate Professor, University of Pécs, Faculty of Law, kecskes.andras@ajk.pte.hu. Acknowledgement: Supported BY the ÚNKP-17-IV-4 New National Excellence Program of the Ministry of Human Capacities. This thematic issue (Missed and new opportunities in world trade. Eds. Csongor István Nagy \& Zoltán Víg) was published as part of the research project of the HAS-Szeged Federal Markets 'Momentum' Research Group.

1 Lentner et al. (2015a), Lenter et al. (2015b). 
For instance, in the case when a fund manager envisages an increase in the price of gold on the global market, it opens a long (purchase) position in that regard. In case it achieves a certain amount of profit with this position, in order to secure (cover) that profit, it opens a short (sale) position with regards to the same instrument, in this case, gold, whilst maintains the original position as well. Thus, the profit generated this way will be lower, since one of the two reverse trading positions will be a loss, however, the other position guarantees a remaining profit.

With regards to the expected market trends, the fund manager, after taking its position, assumes full risk and there is nothing to mitigate the loss as in the case of a wrong decision. When creating its trading approach based on its speculations, the hedge fund does not seek either diversification or risk mitigation, but, in order to achieve the highest possible profits, concentrates all of its financial resources on the establishment of a position speculated to be correct. In the case that the trading concept is successful, the fund manager can, and usually does strengthen its market position with additional financial instruments. Certain derivatives $^{2}$ with more risk, such as leverage, can be found among these instruments, since early successes reinforce the ideas lying behind a trading concept. Afterwards, however, the position is able to achieve such profit that would be unreasonable to be exposed to further risks, thus the fund manager commences reverse trading, the success of which will depend on the fate of the original position.

It is sufficient to a less extent to cover the profit in case the fund manager decides to dismantle or terminate the original position and, while maintaining or extending the original position, it is appropriate to open a reverse position created with higher turnover and backed with derivative instruments.

The hedge fund would be unable to achieve profits above market average in the case of cover all risks. This is the reason why the loan translation of hedge fund into Hungarian results in the wrong meaning as it would mean a reserve fund whilst the essence of hedge funds is to sacrifice reserves for the hope of a higher profit in the initial phase of positioning instead of providing coverage to certain positions. However, defining hedge funds as funds without reserves, a definition widely accepted by the legal profession, would also be incorrect as the management of these funds includes the opening of reserve positions, the extent of which could greatly differ. The ratio of short and long positions is established based on the fund manager's expectations, be it market growth or recession and furthermore, changes in the market and expectations relating to it can be traced down subsequently by altering the ratio of opened positions.

Defining hedge fund in a sectoral manner is also not appropriate ${ }^{3}$ as it is comprised of, and used by, organizations on the market whose interests are dependent upon consumer confidence (or the lack thereof) shown towards hedge funds. Accordingly, hedge funds are defined as investment programs in which the fund managers are aiming for absolute return ${ }^{4}$ with the use of certain investment opportunities whilst preserving the fund's capital at the same time. However, in essence, it is the exact opposite. The absolute return can only mean real profits in the case of the trading concept being an overall success otherwise it

2 Derivatives, also known as derivative instruments, are investment instruments with a price that is dependent upon an underlying asset.

3 Alternative Investment Management Association, AIMA's Roadmap to Hedge Funds (4th edn, 2012), 13.

${ }_{4}$ Absolute return means that the provider of investment services guarantees the profit to its clients independently of market performance. 
results in a loss. This removes the possibility that the fund could maintain safe investments in all circumstances.

Thus, a hedge fund could be considered as an investment being able to provide significant return paired with high risks, even against market trends, usually for well-capitalized clients. It does not limit its investment policy in any form, and the fund manager manages its own capital in the fund as well, thus it takes the same type and extent of risk as its clients. The use of high-risk items (usually derivatives) during the management process, is a widespread practice. The fund's hedging activity solely functions in order to safeguard profits but there is a higher level of capital risk. The legal treatment of hedge funds may vary widely in a global context. ${ }^{5}$ In the course of its investment activities, next to risk management, hedge funds use leverage and derivative transactions as well, and in most cases, it rewards fund managers with performance fees. ${ }^{6}$

\section{THE HISTORY OF HEDGE FUNDS}

The history of hedge funds can be traced back to 1949, when Alfred Winslow Jones ${ }^{7}$ established his investment company, which still has a significant effect on the industry's functioning even after 60 years of its establishment. Jones established his company by recruiting a clientele comprised of ninety-nine investors and thus did not fall under the jurisdiction of the Investment Company Act of 1940 which puts investment companies with a clientele of at least one hundred investors, and asset managers under the authority of the SEC. The company took high risks due to the concentrated nature of its market positions and was the first to apply short position trading ${ }^{8}$ and leverage. ${ }^{9}$ Jones also managed his own capital in the fund, working with a $20 \%$ performance fee. The idea of managing own capital in the fund paired with high performance fees has been deemed as an industrial fundamental principle ever since as these factors are creating harmony between fund managers and investors. Jones pioneered the technique of combining purchase (long) and sale (short) positions in a way that it eliminates systematic risk in the market whilst maximizing risks projected towards certain investment instruments. The reason for this was that system-wide market timing was not one of Jones's strengths but, as he was aware of this, he took long and short positions to an equal extent, however, only one with regards to a given investment instrument. Naturally, he based short positions on securities he regarded as overvalued,

5 See Shadab (2013) 141.

6 See Ashworth (2013) 655-56.

7 Alfred Winslow Jones (1900-1989) started his carreer as a sociologist and financial journalist. He finished his university studies at Harvard and Columbia. His name is strongly bound to the establishment and operation of the first prototypes of hedge funds. He had dealt with professional investments previously but he became well-known in 1966 following a comprehensive review of his approach and activities in Fortune magazine. See Connor and Woo (2004) 12.

${ }^{8}$ Short position means directional trading where the fund manager sells the shares of borrowed stock and expects that the price of the stock will decrease. When the price of the stock decreases, the fund manager will purchase the shares. Thus short position is a type of speculative trading, during which profit is earned in case the price of the investment instrument decreases. The word short originates from the fact that previously such transactions could only be made with short expiration deadlines. Consequently, purchase positions are indicated as long positions.

9 The advantage of using leverage is that it can multiply the profits generated by the investment, however, the same applies to losses as well. This possibility was first utilized by Alfred Winslow Jones during the management of his hedge fund. 
while he opened long positions on the undervalued ones. Therefore, his strategy was based on only considering the expected future performance of certain shares, while being able to act independently of market trends. Furthermore, he made use of the possibility to tie only a smaller portion of his trading capital by using leverage, thus could trade on a higher volume simultaneously with the taking of higher risk. Another one of his innovations was that he did not manage the fund alone but tried to increase efficiency by involving external experts and thus laid down the theoretical foundations of multi-manager hedge funds whilst at the same time created the prototype of fund of funds ${ }^{10}$ investing in hedge funds. ${ }^{11}$ However, from the end of the $1960 \mathrm{~s},{ }^{12}$ hedge funds that applied this same strategy did not achieve successes, as, at that time a permanent growth rate characterized by the Nifty Fifty ${ }^{13}$ shares emerged on the stock market.

Nifty Fifty, according to United states' stock market jargon, indicates those shares which had high capitalization ${ }^{14}$ in the 1960 s and 70 s and their successes were recognized with a P/E ratio ${ }^{15}$ above 50 on the market. ${ }^{16}$ Popular and well-known publicly traded companies $^{17}$ were categorized in this group and include such companies as Coca-Cola, Pepsi Cola, McDonalds, General Electric, IBM and Wal-Mart. Companies investing in their shares achieved, at that time, a return rate of $29.65 \%$ in 29 years.

The permanent growth rate on the stock market did not favour the long/short strategy developed by Jones and hedge funds could not reach the rate of return achieved by the growth of the Nifty Fifty shares. From an economic point of view, this underlines that the long/short strategy of Jones, still being applied by hedge funds to this day, was based on reverse positions which were contrary to certain market trends. In order to catch up with the return rate of the Nifty-Fifty, funds started to apply the long strategy created with leverage

10 The fund of funds is an investment fund which invests in other investment funds. Contrary to other fund managers, the managers of fund of funds do not invest in directly accessible instruments. The advantage of this is that, indirectly however, but opens the possibility to invest is instruments which would otherwise be unaccessable on local markets.

11 Ashworth (2013) 675.

12 See Connor and Woo (2004) 13.

13 See Fesenmaier and Smith (2002) 86.

14 Starting in November 3, 1995, the Nifty 50 index, the leading index of India used the sam name.

15 The Price/Earning indicator is the ratio of the price of a given share and the annual profit generated by that given share. The results of the last 12 months are calculated and adjusted with stock split and calculated with the rates of the initial period. The market average usually shows a value of 15 on the long run.

16 At the peak of the stock market cycle starting in the 1960s the P/E ratio of Avon in 1972 was 65 and Polaroid was 91. During the stock market downfall in 1973, the price of Polaroid shares dropped $91 \%$.

17 A similar umbrella-expression is blue chip, meaning the most reliable and steadily profitable companies. The expression blue chip originates from poker, where the most valuable chip is the blue one with 25 dollars, while red is 5 and white is 1 . According to stock market legends, this expression was already used by Dow Jones Newswire during the 1920s. The Dow Jones Industrial Average shows the overall performances of the 30 biggest companies from May 26, 1986. It usually includes blue chips. The index is not stock market capitalization-wighted, but exchange rate-weighted, which means that the exchange rates of the companies included in the index are combined then divided with a ratio which includes stock split as well. In 2013 an exchange rate change of a dollar meant a 6.42 points change in index points. 
instead of the long/short strategy. This strucked back later as the 1972-74 stock market crash caused significant losses for hedge funds using this strategy. The said market crash resulted in a 10-year decline during which many hedge funds shut down their operations. In 1968 , there were $140^{18}$ registered hedge funds in the United States but this number had decreased to 68 by $1984 .{ }^{19}$

The Tiger Fund, managed by Julian Robertson ${ }^{20}$ in the 1980 s, was the next fund which spurred interest towards hedge funds by achieving a return rate of $43 \%$ in 5 years. The secret of its success was the application of a new strategy known as the global macro strategy which was applied by Roberts with leverage in order to maximize profits. The global macro strategy makes investment decisions based on the analyzation of macroeconomic $^{21}$ and political tendencies and thus this strategy does not make investment decisions in a corporate or sectorial context but is based on a supranational, global and (national) economical view. Roberts, while analyzing foreign exchange markets in 1985, recognized the exhaustion of the USA dollar's growing tendency compared to Japanese yen (JPY) and thus shaped his investment policy by puchasing call options on the cross rate of certain european currencies, Japanese yen and USA dollar. Cross rate is the numerical expression of the value of two currencies compared to each other. In case 1 USA dollar is worth 300 Hungarian forints (HUF), the cross rate of USD/HUF is 300 . A price increase of the said currencies in relation to the USD results in a significant increase in the the value of the call options tied to them. The value of the call options, at that time, were low compared to the currencies functioning as underlying assets and furthermore, the market expected the strengthening of the USD at that time. The increase in the option value resulted in a higher than usual profit for the hedge fund. It has to be taken into account that the yield on the call option becomes in itself significant in the case when profits are achieved as in the course of the transactions the parties apply large-scale leverage. It is not a surprise that hedge funds are envied actors of the business world as they are able to provide exceptionally high profits for their exclusive cliente. Hedge funds are also, at the same time, the target of controversy as they often collaborating in major transactions which were heavy for the public purse, including the development of speculative positions against certain national currencies, leading to well-known currency crises.

György Soros and his managed funds are closely related to this type of activity. The most well-known example is the Quantum Fund and its speculation against the British

18 See: Hedge funds, Leverage, and the Lessons of Long-Term Capital Management Report of The President's Working Group on Financial Markets. p.1. The Department of Treasury, the Board of Governors of the Federal Reserve System, the $S E C$ and the Commodity Futures Trading Commission prepared a report on hedge funds and the LTCM scandal for the president of the United States. In the report they reviewed, among others, the historical background of the industry. According to a 1968 SEC report in that year 140 hedge funds existed.

19 See Connor and Woo (2004) 13.

20 Julian Robertson (1933-) finished his business administration studies at North Carolina University in 1955. He worked as a broker for Kidder, Peaboady and Co. for 20 years. In 1980, he established Tiger Management Group and during his active years he acquired the moniker 'Wizard of Wall Street' after securing an annual return rate of 32\% between 1980 and 1996 . His favourite saying was 'let us select the best 200 publicly traded companies and play for their increase and select the worst 200 and with short sales speculate on their decrease. In case the best 200 does not perform better than the worst 200 it is time for us to look for another job'.

${ }^{21}$ Macroeconomics determine the functioning standards of economic systems, contrary to microeconomics, which describes the mechanisms of unit-level economic collectives. 
currency (GBP) and the Thai baht (BHT), where the Quantum Fund applied the global macro strategy. In 1992, Quantum Fund speculated on the weakening of the GBP and took advantage of the crisis of the European Exchange Rate Mechanism. ${ }^{22}$ At that time, it opened short positions with high leverage, achieving an estimated profit 10 billion USD. The English central bank was not able to protect the exchange rate of the GBP - even with a significant interest rate increase ${ }^{23}$ and the GBP cross rate decreased from 2.95 to 2.4 compared to the German mark (DM). The $16^{\text {th }}$ September 1992 went down in the history of English economy as Black Monday. Market estimates suggest that this speculation resulted in a loss of 3 billion GBP to English taxpayers. It also established the long-term negative connotation of Soros-managed funds. The next high-profiting transaction was against the BHT, where the Soros-managed fund speculated that the government of Thailand would not be able to protect the fixed exchange rate ${ }^{24}$ of the BHT compared to the USD (the cross rate of 25). In April 1997, Soros opened lucrative positions based on the devaluation of the $\mathrm{BHT}^{25}$ and on $2^{\text {nd }}$ July 1997, following an unsuccessful effort to protect their national currency, the Thai government had to let the fixed exchange rate float free. The free float phenomenon $^{26}$ in financial terminology literally lets the free flow of events. The consequences were once again suffered by the public, however, unlike the British scenario, this speculation was directed against a financially unstable and economically unprepared country. The British speculation involved the serious devaluation of national currency $(18.6 \%)$ but it was not a fatal blow to the UK economy. However, the Thai speculation resulted in the collapse of the national economy and the total elimination of the BHT's stability. Consequently, the Thai central bank had to turn for assistance to the International

22 The European Exchange Rate Mechanism (ERM) is an international payment system established by the European Economic Community on the 13th March 1979 with the purpose that the European Economic Community could establish ERM as a part of the European Monetary Union. The ERM paved the path for the introduction of the euro. The aim was to decrease the exchange rate fluctuation between currencies and bring the member states of the European Economic Community (later, the European Union) closer to financial stability. The targeted aim was achieved in January 1, 1999 with the introduction of the euro

${ }^{23}$ See Dhar (2016). In September 16, 1992 the English central bank raised the base interest rate from $10 \%$ to $12 \%$, and to $15 \%$ on the same day, following the unsuccessful protection of the pound's exchange rate during a 1 billion pound intervention. That was the time when Soros said 'go for the jugular'.

24 The aim of fixed rate or pegged rate exhange rate systems is the stabilization of the national currency by tying it to another national currency, the basket thereof or e.g. gold. This way the position of the given national currency could be stabilized in the international financial markets. However, a prerequisite of this is that the national bank protects the currency with the constant sale or purchase thereof. The downside of fixed rate is that it prevents independent monetary politics and only a part of the national bank's currency reserves can be used for the protection. In the case that the national currency is under pressure from price-decrease then with a capital bigger than the currency reserves then the forfeiture of the the fixed rate can be achieved in the financial market.

${ }^{25}$ See Forex Illustrated (2013). In July 1997 Soros warned the people of Thailand of the possible price-decrease of their national currency and the crisis emerging as a consequence. However, the Thai national bank intervened with 7 billion US dollars just when the Thai baht became stronger compared to the US dollar, turning the previous investments of Soros into a loss.

${ }^{26}$ In the case of a free floating exchange rate system, the national bank does not tie the exchange rate of the national currency to another currency or the basket thereof, but, rather to the contrary, it lets market demand and supply determine the exchange rate of the national currency. 
Monetary Fund (IMF) who approved the loan package requested by Thailand. However, strict economical and social constraints had to be implemented by the Thai government as a condition of the loan. By December 1997, the exchange rate of the BHT increased to USD/ BHT 55, when the management of Quantum Fund decided to close its positions, earning a profit of USD 790 million.

However, not all transactions carried out by hedge funds resulted in such notable profits in the 1990s and some funds suffered huge and considerable losses. Quantum Fund and Tiger Fund both lost USD 2 billion during these times. The Soros-maganged fund suffered massive losses due to the Russian stock market crisis while the fund managed by Roberts speculated the devaluation of the JPY. Both strategies failed as the positions were established contrary to future market movements. The assessment of the United States infocommunication sector, the aptly named dot-com sector, became exhausted in 2002 and was a particular sector that caused headache to hedge funds and featured significant investments of the two above-mentioned funds. Quantum Fund lost USD 3 billion with the opening of short positions while the shares of the dot-com sector were flying high. The problem was not with the strategy direction, but the timing. The subsequent events of the market confirmed the overvaluation of the shares appearing in the sector. Likewise, it was correctly assessed by the Tiger Fund that the increase in the dot-com sector was unstable, however, it applied a more refined and complex investment strategy by the simultaneous opening of short positions on dot-com shares and long positions on shares from other, more traditional industry sectors. In their case, however, wrong timing proved to be fatal, as the fund had to shut down its operations in March 2000, following the complete loss of their creditors' confidence and the withdrawal of the invested capital. It is ironic that an amount of profit, never seen before, could have been achieved if the above-mentioned positions were opened by the hedge funds at the right time.

The most emblematic and important event in the history of hedge funds was the fall of the Long-Term Capital Portfolio L.P. managed by the Long-Term Capital Management L.P. (LTCM). This hedge fund was established in 1993 by Nobel-Prize winning mathematicians and economists ${ }^{27}$ and was led by John William Meriwether (1947-), ${ }^{28}$ the former vicepresident and head of the stock market department of the Salamon Brothers investment bank. The fund wished to apply a strategy exploiting the opportunities of very low extent arbitrage ${ }^{29}$ and is also known as the quantitative strategy. ${ }^{30}$ The question arises how a scientifically backed and seemingly successful idea could be a failure in the practice of

27 Robert Cox Merton (1944-) and Myron Samuel Scholes (1941-) were professors at Harvard and Stanford who received economic Nobel prize in 1997 for elaborating the model for determining the value of derivatives transactions. Fischer Black passed away in 1997 thus could not receive the Nobel prize, however, the Noble Committee mentioned Black and his contribution to the model. The Black-Scholes model provides framework for the valuation of sale and purchase options.

${ }^{28}$ It is worth mentioning that investment activities of John Meriweather have not been successful ever since. In 2002, he established another hedge fund which went bankrupt as the result of the 2007 subprime crisis.

${ }^{29}$ Arbitrage is a financial instrument which is traded on different markets and on different values. Consequently, in case of the establishment of simultaneous selling and buying positions it can provide safe investment opportunities.

${ }^{30}$ During quantitative investment strategies a large amount of financial data is being examined in a fast manner, which is able to provide quickly tradeable information to the one who applies the strategy. 
financial market mechanisms? The idea was based on the convergence theory ${ }^{31}$ used in mathematics and the fund took advantage of the interest rate difference between bonds issued by certain member states in the European Union. This strategy was based on the assumption of persistently low volatility ${ }^{32}$ and high liquidity. However, they could only ensure big profits with the application of high leverages next to low interest rate differencies, therefore the hedge fund, next to its capital of USD 4.8 billion, requested a loan of USD 120 billion and thus the investment exceeded the fund's own assets by twenty-five times, indicating the use of a surprisingly high volume of external sources. However, as this investment capital was increased with leverage, the nominal exposure ${ }^{33}$ of the fund reached USD 1200 billion. This economic model was viable until the outbreak of the Russian stock market crisis in 1998.

However, after 1998, low volatility increased and liquidity decreased simultaneously and this was time when the two basic conditions of the hedge fund's functioning model collapsed and both started to work against it. The dramatic increase of volatility resulted in the hedge found not being able to close its positions with a low rate of loss. Consequently, it was not able to pay the loan of USD 120 billion back to the lenders (banks) and it lost its credit solvency. Thus, on the weekend of $19^{\text {th }}-20^{\text {th }}$ September 1998 , the FED - with fourteen financial institutions - organized a liquidity loan for the hedge fund in order to save LTCM from the forced sale of its existing positions. The situation where the central bank of the United States, for the sake of only one fund, directly mediates between a hedge fund, on the edge of solvency, and other market actors is rather controversial. The reason behing this unusual step by the FED was based on the prediction that the bankruptcy of LTCM would directly endanger certain financial institutions providing sources to it beforehand and would lead to system-wide market recession.

The popularity of hedge funds remained undiminished, despite the difficulties and highlighted huge losses. This is well-illustrated by the USD 11 billion investment by one of the world's biggest institutional investors, the California Public Employees Retirement System (CALPERS) ${ }^{34}$ in certain hedge funds 1 year after the fall of LTCM. ${ }^{35}$ By the end of the 1990s, the dynamic growth created a new type of method. Hedge funds started to invest in other hedge funds-a fund of funds in the financial terminology. Nowadays, however,

31 The basis of convergence theories is the assumption according to which the value of various associated variables are in the same direction or level.

32 Volatility means the extent of the temporal movement of a given financial instrument. It indicates the zone in which the the financial instrument moves in a given time period. A large movement zone means a greater volatility, and vica versa.

33 Nominal exposure means the overall possibility of financial losses which can be suffered by the investment institution with taking into account the maximum losses its positions can generate. The concept is used to determine the biggest possible loss which can be suffered by an investment fund (or other institution) with regards to the capital managed by it.

${ }^{34}$ CALPERS is the pension fund of the state of California, and one of the biggest institutional investors in the world. Its investment portfolio is complex, ranging from venture capital investments to derivatives based on shares issued by publicly traded companies. For Hungarian lawyers and economists, it could be strange that one of the biggest institutional investors in the world is a stateowned pension fund, however, in the United States pension funds try to increase the value of their savings with bigger capital and a more active approach on the market.

35 See Connor and Woo (2004) 17. 
funds of funds do not necessarily operate as hedge funds, but in a differently controlled ${ }^{36}$ and regulated institutional form. In the investment world, it is common knowledge that the funds of funds only work with direct investments, e.g., by acquiring a certain amount of shares in hedge funds, therefore, investing in hedge funds nowadays became an option for smaller investors as well.

Diversification ${ }^{37}$ can appear in in the case of funds of funds operating as a hedge funds in two different forms. The first divides its capital between hedge funds applying different investment strategies, while the second form does the same between hedge funds with identical investment policy. ${ }^{38}$ It is not uncummon for certain funds investing in hedge funds to go public. The Alternative Investment Strategies Ltd. ${ }^{39}$ in 1996 was the first hedge fund investing in other hedge funds which decided to go public in the London Stock Exchange. It was involved due diligence experts as well as new investors, resulting in an increased extent of transparency as in general hedge funds disclose only a small amount of information regarding their investment policies. Therefore, funds investing in hedge funds combine the efficiency and knowledge of hedge fund managers with the criteria of increased transparency, which is expected in case of a wider circle of investors. However, the advantege of increased transparency increases transaction costs for the clientele as well, as it is incorporated in the budget system as a price-increasing factor. This leads to the dramatic increase of investment costs based on the cumulative surplus of competency expressed on two levels, since next to the expertise and knowledge of the hedge fund's management the costs of management add up as well. For example, a 2\% base price and a performance fee of $20 \%,{ }^{40}$ common among hedge funds, ${ }^{41}$ then in the case of a fund of funds a $4 \%$ base price and a performance fee of $40 \%$ might encumber the gross rate of return. The high costs of management can be reduced, however, only to a small extent. The performance fee of $20 \%$ ( $40 \%$ in case of fund of funds) applies only to the part of the total annual return which exceeds the one in the previous year.

\section{THE STRUCTURE OF HEDGE FUNDS}

The most efficient way to understand the special structure of hedge funds is by taking into consideration that their main goal is to be exempted from certain regulations applicable to institutional investors. This special status is required in order to avoid certain regulatory and supervisory authorities and their willingness to treat hedge funds similarly to other investment funds and to increase transparency for a wider circle of investors. Hedge funds wish to constantly reinforce their exclusive characteristics by reserving a degree of flexibility in taking their decisions, which other investment funds do not possess and furthermore, they wish to hide their investment strategies from the public eye as long as possible. Simultaneously, they wish to maintain the most motivating and stimulating

36 Zéman et al (2014) 217-21.

37 Diversification is a process during which the managed capital is allocated with the use of several investment instruments, decreasing the risks of that specific investment instruments. Diversified investment portfolios do not ensure avoiding losses, however, they decrease extremely high risks to the level of market or sectorial systemic risk.

38 Investment policies require the appropriate accounting policies. For a method for their development, see Zéman et al. (2012) 106-17.

39 See Connor and Woo (2004) 17.

40 See Shadab (2013) 152.

41 Ashworth (2013) 658. 
remuneration system for their fund managers as another exclusive characteristic. These characteristics stand opposed to the requirement of reliable, transparent and prudent investment policy requested by supervisory authorities and the consumers. In order to unlock these two seemingly contrary interests, hedge funds seek to partially or completely avoid certain regulations mentioned above. Most hedge funds operate in the United States and they all seek to be exempted from the Investment Company Act of 1940 as it creates a substantial amount of administrative burden as well as disclosure obligations, furthermore, it limits the use of certain investment techniques such as leverage or concentration. However, the Investment Company Act of 1940 itself provides certain loopholes for companies to be exempted from its provisions, as in the case of a clientele of less than a hundred investors, the criteria mentioned above does not have to be fulfilled. Accordingly, both the Quantum Fund and the Tiger Fund followed Jones's footsteps and were established with the involvement of 99 investors. From 1996, the act was amended sothat the number of investors may increase above one hundred in the case of qualified purchasers. ${ }^{42}$ In order for this to happen the qualified purchaser ${ }^{43}$ has to have a capital of at least USD 5 million as a private individual while the institutional investor has to manage a capital of at least USD 25 million.

In order to hide their deal strategies (ratio of long/short positions, leverage ratios and derivatives transactions) involving proprietary trading ${ }^{44}$ from the public eye, hedge funds seek to be exempted from the provisions of the Securities Act of 1933, which sets forth certain disclosure and registration obligations. It is also important that such data does not get in the hands of competitors as a result of certain statutory requirements. Furthermore, by being exempted from these obligations, hedge funds save a considerable amount of compliance costs. However, hedge funds have to accept that they are not allowed to raise capital publicly, only in accordance with the rules applicable to the private placement process. Furthermore, the number of investors with a capital below USD 1 million and an annual income below USD 200,000 have to be kept under $35 .{ }^{45}$ In order to operate efficiently and comply with statutory requirements simultaneously, within their necessarily limited clientele, hedge funds have to concentrate on investors with large capital. The only way to grow is by having a circle of investors capable of providing a large-scale capital for the fund as the potential lying in capital allocation decreases due to the narrow circle of participants. In the context of regulations enacted after 1996, this means that the most efficient hedge funds limit the number of those participating investors which are limited by the law to the minmum. It is obvious that belonging to a private circle creates a massive

42 Section 51/A of Investment Company Act of 1940.

43 Bárczi and Zéman (2015) 101-08.

44 Proprietary trading means that a company issues its own shares for its employees trading with shares and provides the possibility of leverage for traders as well, thus the company can take the profit of the entire transaction (contrary to the maximum brokerage fee of 1-2\%). However, the overall risk (multiplied in case of leverage) with this method is also taken by the company. Following the 2008 subprime crisis, the proprietary trading activities of investment banks was significantly limited in the United States (down to 3\% of the company's own capital in accordance with the Dodd-Frank Act).

45 The regulations governing the private placement of shares limit the issuance or purchase of shares to a narrow circle of investors in a global context. Typically, irrespectively of the characteristics of the private placement process, such placement can occur with limited value and in limited numbers. Simultaneously with the determination of the narrower scope of owners or investors, the volume of the potential sources to be allocated decreases as well, while less obligations arise with regards to disclosure towards the public. 
advantage, as these investors represent the ones with smaller capital, however, due to their luck or good sources of information they are able to achieve big profits - they are given the chance to play with the big guys.

Most hedge fund managers also seek to be exempted from the registration requirements set forth by the Investment Advisers Act of 1940 - this is possible if the fund manages a capital smaller than USD 150 million in the form of a hedge fund or if it complies with the criteria of being a foreign private adviser. ${ }^{46}$ The act also sets forth that the adviser has to register at the Securities \& Exchange Commission (SEC). In this case, however, the SEC will be entitled to request certain information and supervise the activities of the manager. Furthermore, by registering, the fund manager would accept the limitation of its own remuneration as it could only receive compensation proportional to its performance. Thus, it would have to let go of the base price determined as a percentage of the total assets managed by it (usually 1-3\%), which is due regardless of the fund's performance. Nevertheless, there are hedge fund managers who register with the SEC in order to gain the additional trust of investors.

From a taxation point of view, hedge funds are distinguished from traditional investment funds - the institution hedge funds are the closest related to - by the company form they are operating under, and their place of registration. Hedge funds are established as partnerships or limited liability partnerships ${ }^{47}$ in order to avoid double taxation applicable to stock corporations. ${ }^{48}$ In the case that the company would pay the dividends from the net profit, the clients would have to pay dividend tax as well.

Furthermore, two-third of hedge funds operating in the United States ${ }^{49}$ are registered as offshore companies outside the US in order to exploit the benefits of lower corporate tax for the sake of additional tax optimization. Interestingly, not all the hedge funds operating in the US are registered in well-known tax havens such as the Cayman Islands, British Virgin Islands, Bermuda or the Bahamas, but also in Luxembourg and Ireland. ${ }^{50}$ These two European states, contrary to the US, allow the advertising of hedge funds and do not limit investment capital. Furthermore, they allow hedge funds to go public and issue their share via public placement. ${ }^{51}$ Ireland, for instance, within the sphere of the Qualifying Investment

46 Prior to the Dodd-Frank Act, 'foreign private adviser' was determined by the applicable law as an investment adviser (with regards to the sale and purchase of shares) having less than fifteen clients from the USA and not performing such advisory activities in the USA. The Dodd-Frank Act has made these limitations even narrower. With respect to the limit of 25 investors, the clients of private funds have to be taken into account as well, furthermore, it should have no registered seat in the USA and does not perform advisory activities for registered investment and development companies. Along with these conditions, only a small-scale fund can be operated as a foreign private adviser instead of a hedge fund, just as it could have been targeted by the legislator of the Dodd-Frank Act.

47 See Shadab (2013) 153.

48 In the United States, civil law governs 'partnerships', the establishment of which does not necessarily require strict formalities and official registration. However, in case of hedge funds, partnerships are more like European business organizations with a strong cooperative (partnership) nature, like a general partnership. These similarities also manifest in the fact that while the members of general partnerships have unlimited liability with regards to the debts of the company, only limitied liabilities can be found among the members of limited companies.

49 See Shadab (2013) 155.

50 See Browne (2012) 2.

51 See Browne (2012) 7. 
Fund (QIF), ${ }^{52}$ allows the advertisement of hedge funds and determines minimized restrictions with regards to their investment policy. The more flexible regulatory framework means that, based on its own expectations and willingness to take risks, the hedge fund manager can freely use leverage while its only obligation being disclosure via the fund prospectus towards investors regarding the extent of leverage applied and describing the way it is used. In Ireland, the regulation is narrow, it only includes counter-party risk ${ }^{53}$ and limits investment (to a maximum of $50 \%$ ) in certain unregulated funds. ${ }^{54}$ It is not a coincidence that according to a 2011 survey $63 \%$ of European hedge funds and $40 \%$ of hedge funds operating globally are having their registered seat in Ireland. ${ }^{55}$

\section{THE REGULATION OF HEDGE FUNDS IN THE UNITED STATES}

The desire towards the system-wide regulation of hedge funds in the United States emerged with the fall of the LTCM. ${ }^{56}$ However, more than ten years had to pass before the first substantive actions were taken. The 2007-2008 subprime mortgage crisis once again raised awareness of the role of hedge funds and the extent to which they could endanger financial stability, even if they were certainly not the central point of this particular crisis. During the crisis, the question arose whether hedge funds are able to increase and spread potential risks across the entire financial system.

The roles of certain institutions financing hedge funds (prime dealers) ${ }^{57}$ are usually taken by the biggest investment banks. These banks ${ }^{58}$ provide loans which form the basis of the increased trade capital of hedge funds. Increased trade capital is used by hedge funds in derivatives transactions with the possibility of multiplying the profit (or loss). However, it has to be taken into account that hedge funds, typically to proprietary trading activities, put the overall capital at risk. This is different from clients taking all the risk of the brokerage activities of investment banks and companies. The sole risk factor investment banks have to take is the loss of the brokerage fee in case their transactions fail. With the involvement of

52 Hedge funds meeting the two following criteria can be deemed as Qualifying Investment Funds (QIF): It determines savings above EUR 100,000 as a minimum amount for investment and only manages the investments of investors qualifying as professional investors in accordance with Annex II of Directive 2004/39/EC (Markets in Financial Instruments Directive) and backed with MIFID tests underlining their expertise. See Browne (2012) 2.

53 Counter-party risk is a contractual risk which originates from certain liquidity problems arising among contractual partners. For example, in case the fund manager purchases a block of shares from its partner being under the pressure from risks arising with the default of the transaction of shares. Real risk originates from the deficiency of regulations, since in a reliable environment there are institutional warranties safeguarding the fulfilment of certain obligations, for example with the involvement of clearing houses.

54 Funds falling outside of the scope of regulations applicable to hedge funds.

55 See Browne (2012) 1.

56 See Ashworth (2013) 669.

57 Interestingly, the expression 'prime dealer' i.e. a financial institution directly financing a hedge fund, is not translated to Hungarian by Act XVI. of 2014 but is used in its original English version.

58 Lentner (2013). 
clearing houses, the non-performance risk of contractual partners participating in the deal can be reduced to a minimum on the stock market (or on other regulated markets). ${ }^{59}$

However, in the case that the hedge fund loses its increased capital, the investment bank, as the institution financing the hedge fund, can record a major loss as well. In the case it is applied on a large scale by investment bank, and, due to other reasons, a crisis has already emerged on the markets, this financing method has the potential to put the entire market in danger. There was a good chance for such systemic risk to appear after the fall of the LTCM. ${ }^{60}$ However, it was resolved by creating a controlled insolvency situation with the help of the rescue package, thus the stability of the financial system was maintained. It was important achievement, as the earthquake-like fall of the hedge fund could have caused a domino-effect the collapsing the investment banks which would have endangered the liquidity of commercial banks.

In order to achieve higher profits, the investment banks have used their trading capital for proprietary trading and thus used short-term loans borrowed from commercial banks to finance hedge funds. However, the investment banks would not be able to pay back, these loans to the commercial bank in case the hedge funds did not repay their loan to them in the first place. In case the FED did not intervene once again in 2008 following the bankruptcy of Bear Stearns, the chain reaction described above would have materialized as a real threat.

The new act seeks to eliminate situations where such measures have to be taken at the cost of taxpayers. Therefore, the main goal of the Dodd-Frank Wall Street Reform and Consumer Protection Act (commonly known as the Dodd-Frank Act) was to strengthen financial stability. The proposed legislation had already been presented by the Obama Administration in July 2009 however, only entered into force on July 20, 2010. Following several amendments, Barney Frank (the then chairman of the Committee on Financial Services) represented the proposal front of the U.S. House of Representatives, and at that time the chairman of the Senate Banking Committee was Chris Dodd. In recognition of their main role played in the creation and enactment of the act, the name of the two politicians was included in the title. The title of the act is meaningful, as it promotes the strengthening of system-wide financial stability. ${ }^{61}$ In order to achieve this target, the act promotes the increase of accountability and transparency in the financial system and to that end it established the Financial Stability Oversight Council (FSOC) as an intergovernmental organ and the Office of Financial Research under the control of the U.S. Department of the Treasury, two supervisory authorities with monitoring activities and intervention rights. The title of the act also suggests that the 'too big to fail' concept has come to an end. However, for taxpayers the protection from the burden of similar rescue packages in the future is what matters the most as it is common knowledge that the costs of the state's rescue packages are deducted from the federal budget and indirectly from the pocket of taxpayers. Nevertheless important, the act promotes the protection of consumers from abusive financial service practices.

59 The function of cleaning houses is to decrease to the minimum the contractual risk for its members by entering into the contract instead of its member and ensuring the fulfilment of the obligation. For this purpose, cleaning houses establish and operate a system of rules being able to secure the fulfilment of certain obligations in case of significant market shifts as well.

${ }^{60}$ Riviére (2011) 265.

${ }^{61}$ An Act to promote the financial stability of the United States by improving accountability and transparency in the financial system, to put 'too big to fail' to an end, to protect American taxpayer by ending bailouts, to protect consumers from abusive financial services practices and for other purposes. 
Basically, the Dodd-Frank Act affects the operational framework of hedge funds in three different aspects. First, it sets forth that hedge funds managing a capital of USD 150 million or above have an obligation to register ${ }^{62}$ with the U.S. Securities and Exchange Commission (SEC). ${ }^{63}$ Thus the managers of the hedge funds were no longer able to decide on their own whether they wish to avoid supervision and focus only on clients with a bigger capital or limit the number of investors. The obligation to register with the SEC creates a substantial amount of admininstrative burden for the fund manager. Among others, the fund manager has to keep certain records in order to evidence in case of a SEC investigation the fact that in the course of its investment activities it excluded conflict of interest between executive officers and the fund. In order to meet with transparency requirements set forth by the Dodd-Frank Act hedge funds have to employ chief compliance officers. The task of the chief compliance officer is to work out and operate a compliance program which gets in the spotlight during periodic SEC inspections or investigations. However, the competence of the SEC increased even further by having the right to oblige mid-sized hedge funds to register. Furthermore, the SEC might request additional information and reports from other hedge funds as well.

The Dodd-Frank Act brought hedge funds under direct regulatory supervision with a new method, the commodity pool, which usually mandates external advisers (commodity pool adviser) ${ }^{64}$ to manage the raised capital. Hedge funds can be deemed as institutions investing in stock market transactions and have as their sole purpose the enhancement of leverage by combining and managing investments as a single unit. These units became the centre of interest since certain traders (Commodity Futures Traders, Commodity Futures Operators) were obliged to register with the Commodity Futures Trading Commission (CFTC) for the successful monitoring of systemic risk in future tradings.

The Jumpstart Our Business Startups Act of 2012 (JOBS) lifted the previous restriction, according to which hedge funds were only allowed to seek and advertise themselves to qualified investors $^{65}$ or qualified institutional investors. Section 201 of the JOBS Act exempts hedge funds from this limitation as it amends certain provisions of the Code of Federal Regulations relating to the functioning of the SEC in a way that it permits hedge funds to seek investors in a wider sphere, provided that the hedge fund registers with the SEC in accordance with Formula $\mathrm{D}^{66}$ of the JOBS Act. Consequently, the issuer of securities is able to seek any kind of investor and is allowed to advertise itself to anyone, however, can only market to investors defined as qualified investors by the JOBS ACT.

62 Ashworth (2013) 684.

63 Ashworth (2013) 654.

${ }^{64}$ Commodity pool advisor is a private individual or a company managing a fund investing in commodities. Commodity pool operator is the company providing administrative and depository services to the fund investing in commodities.

${ }^{65}$ Irrespectively of loans and the primary residential property, a private individual (or a private individual together with their spouse) has a net wealth of USD 1 million at the time of the registration. The second option is that the client had an annual wage of minimum USD 200,000 in the last two years and is likely to acquire the same amount in the upcoming years, or together with his/her spouse they had an annual wage of USD 300,000 in the last two years and are likely to acquire the same amount in the upcoming years as well.

66 The Securities Act of 1933 provides two opportunities for a company in case of the placement of shares. It can register with the SEC in accordance with a strict procedure, or by applying Sections 504, 505 and 506 of the Act it only fills Form D out, evidencing the fulfilment of one of the three requirements. 


\section{THE REGULATION OF HEDGE FUNDS IN EUROPE}

Europe chose a different path in the regulation of hedge funds as the United States. European Union lawmakers realized in 2010 that controlling the growing number of hedge funds is an impossible mission, and the only way to successfully regulate their functioning is through the implementation of certain rules applied to fund managers. For this purpose, Directive 2011/61/EU on Alternative Investment Fund Managers (AIFM Directive) was created. The AIFM Directive also contains certain exemptions, according to which alternative investment funds ${ }^{67}$ managing a capital below the threshold of EUR 100 million and funds managing an unleveraged capital below the threshold of EUR 500 million and not granting redemption rights to investors for 5 years are exempted from certain provisions of the AIFM Directive. Based on the AIFM Directive, fund managers are able to choose from two different functioning models. The first is a traditional functioning model under Directive 2009/65/EC on Undertakings for the collective investment in transferable securities (UCITS). The other model has to function in compliance with the rules set forth by the AIFM Directive.

In March 2009 the AIFM Directive set forth certain targets ${ }^{68}$ with respect to the alternative investment fund industry. The first and most important is macro-prudential risk management. In the context of alternative investment funds, macro-prudential risk means systemic risk during which the collection of macro-prudential data takes places in a coordinated way and, in accordance with the lawmakers' will, data is processed within the cross-border framework of prudential authorities. ${ }^{69}$

Furthermore, the management of micro-prudential risks is also amongst the targets of the AIFM Directive. Micro-prudential risks are the type of risks which appear in the context of certain services and service providers. Management of micro-prudential risks proved to be important for the European Union as previously there were no appropriate methods to supervise the risk management practices of alternative investment funds. The weakness of risk management practices endangers investors, contractual partners and the market as a whole, while consistent regulation mitigates that risk, and cross-border regulations can reduce the possibility of supervisory authorities engaging in regulatory arbitrage. ${ }^{70}$

The financial crisis of 2007-2009 once again confirmed the need for intervention for the sake of investor protection. Despite that clients of alternative investment funds are usually professional investors, nonetheless they require reliable and comprehensive information services. Previously, the domestic legislation of member states applied a different approach than the EU with respect to corporate governance and disclosure obligations, thus they were not able to provide consistent legal foundations for the reliable functioning of alternative investment funds.

${ }^{67}$ Alternative investment funds are different capital-raising organisations, thus they fall outside of the scope of regulations applicable to traditional investment funds. Alternative investment funds do not emphasize the establishment of diversified portfolios but rather apply large-scale leverage and engage in derivatives transactions.

68 See Commission (2012) 8.

69 Prudential regulatory authorities are the capital market authorities.

${ }^{70}$ In the course of a regulatory arbitrage, certain service providers select a country as a place of their operations which is more favourable or less strict with regards to regulations. This decision can incur additional costs, however, the main target is functioning with less burdens. 
In the context of alternative investment fund management, the standardization of market rules is able to increase financial stability and the integrity and efficiency of the markets irrespectively of their location.

Hungarian legislation has implemented the AIFM Directive with Act XVI. of 2014 on Collective Investment Trusts and their Managers and Amending Certain Finance Related Acts and with Government Decree No. 78/2014. (III. 14.). ${ }^{71}$ Furthermore, the Hungarian regulatory regime applies the framework conditions of the AIFM Directive and implements concepts such as prime dealer ${ }^{72}$ and determines feeder funds and master funds. The Act uses the term feeder fund for funds investing in other funds, while funds being the subject of investments are determined as master funds (a type of umbrella fund).

Similarly to the AIFM Directive, Act XVI. of 2014 exempts funds from certain obligations which manage a capital below the threshold of EUR 100 million and funds which manage an unleveraged capital below the threshold of EUR 500 million and does not grant redemption rights to investors for 5 years. ${ }^{73}$

However, contrary to the EU regulatory framework, Hungarian legislation applies Act XVI. of 2014 to funds with the characteristics mentioned above but exempts them in four different aspects. These aspects are in connection with remuneration, risk and liquidity management, redemption policy and consistency between the latter two systems. ${ }^{74}$

The Hungarian regulation also implements the policy of variable remuneration as well, including deferred portion, since a minimum of $40 \%$ of the performance-based remuneration has to be deferred over a period of 3-5 years. ${ }^{75}$

Despite the fact that EU legislation does not approach hedge funds in a manner similar to that of the United States, it seems that the Hungarian regulatory framework allows them a wider room to maneuver. Section 23 (2) of Government Decree 78/2014. exempts hedge funds from certain stricter rules in case the expression 'derived investment fund' is included in its name furthermore, it has to meet one of the two following criteria. Firstly, the initial investment made by an investor in the fund has to be at least HUF 10 million and secondly, the shares of the fund can only be marketed to professional investors. In the case that these conditions are fulfilled, the overall risk exposure rate of certain positions in derivatives transactions can be specifically determined. Through this method an alternative fund may be established which incorporates two basic characteristics of hedge funds, i.e. large-scale investors and high leverage. Performance-based remuneration is partly deferred. The investments of the fund manager and the investors in the same fund, furthermore, the management thereof can only occur with the involvement of a third person.

${ }^{71}$ Government Decree 78/2014. (III. 14.) on the regulations governing collective investment forms and borrowing.

72 Prime dealer is the financial service provider providing not only account management but financing services. In the United States, this role is usually taken by investment banks, while in Europe commercial banks are more likely to act as prime dealers.

73 Section 2 (2) of Act XVI. of 2014.

74 Act XVI. of 2014. allows exemption from its Section 33, 35 (1), (3), (5) and Section 36.

75 Annex 13 of Act XVI. of 2014. 


\section{CONCLUSIONS}

In light of this paper, it can be stated that in the investment world, hedge funds are the funds promising high profits, however, this is paired with risky investment policy and usually trading in one direction. Their popularity is undiminished, even if in many cases their investment policies causes losses to investors and their trading strategies are against the interests of certain national economies. The legal regulation of hedge funds is still flexible even though there were several attempts both on European and global levels by legislators to set a framework for their functioning following the 2007 crisis. These regulations could not hinder hedge funds in applying their techniques and achieveing their goals. The reason of this is that the services of hedge funds are mainly used by the 'high society' of investors fond of trading strategies promising higher profits along with higher risks. Hedge funds do not generate, but rather secure the circumstances in accordance with the market demand. Hedge funds are interested in the creation of an overly motivated sphere of investment, which, taking into consideration low interest rates, is able to provide outstanding profits to clients. The uncustomary strategies of hedge funds have also had a significant impact on the approach taken by traditional investment funds.

However, it has to be taken into account that the systemic risk emerging in the wake of hedge funds had been recognized by most states and thus stricter rules have been implemented as a consequence of past experiences. These reforms could be justified or called into question based on market events in the upcoming years and will be largely based on the degree of efficiency shown by state-and federal regulatory authorities.

\section{LITERATURE}

Alternative Investment Management Association, AIMA's Roadmap to Hedge Funds (4th edn, 2012), $<$ https://www.aima.org/uploads/assets/uploaded/1225c1ba-f62b-439a-904d60564a441200.pdf > accessed 27 April 2017.

Ashworth II, Luther R., 'Is Hedge Fund Adviser Registration Necessary To Accomplish The Goals Of Dodd-Frank Act'S Title IV?' (2013) 70 Washington and Lee Law Review 651-703.

Bárczi Judit and Zéman, Zoltán, 'A pénzügyi kultúra és annak anomáliái' (Financial Culture and its Anomalies) (2015) 11 Polgári Szemle 101-08.

Browne, Mark, Hedge Funds In Ireland (Mason Hayes \& Curran 2012) $<$ http://www.hedgefundassoc. org/documents/FG/hfa/documents/233893_hedge-funds-in-ireland-mhc-jan-2012.pdf $>$ accessed 27 April 2017.

Connor, Gregory and Woo, Manson, An Introduction To Hedge Funds (1st edn, Financial Markets Group - London School of Economics and Political Science 2004).

Dhar, Rohin, 'The Trade Of The Century: When George Soros Broke The British Pound' (2016) Priceonomics <https://priceonomics.com/the-trade-of-the-century-when-george-soros-broke/> accessed 27 April 2017.

European Commission, 'Commission Staff Working Document Impact Assessment Accompanying the document Commission Delegated Regulation supplementing Directive 2011/61/EU of the European Parliament and of the Council with regards to exemptions, general operating conditions, depositories, leverage, transparency and supervision' SWD (2012) 386 final, 2012. December 19.

Fesenmaier, Jeff and Smith, Gary, 'The Nifty-Fifty Re-Revisited' (2002) 11 The Journal of Investing 86-90.

Forex Illustrated 'Trading Strategies - 3 Biggest Forex Trades Of George Soros' (2013) Forex Illustrated $<\mathrm{http}$ //forexillustrated.com/trading-strategies-biggest-trades-soros/ $>$ accessed 27 April 2017.

Lentner, Csaba, 'A bankszabályozás tudományos rendszertana és fejlödéstörténete (The System and Development of Bank Regulation) in Lentner, Csaba (ed), Bankmenedzsment: bankszabályozás pénzügyi fogyasztóvédelem (Nemzeti Közszolgálati Egyetem 2013) 27-86. 
Lentner, Csaba, Szegedi, Krisztina and Tatay, Tibor, 'A Központi Bankok Társadalmi Felelőssége' (Social responsibility of central banks) (2015a) 46 Vezetéstudomány 35-47.

Lentner, Csaba, Szegedi, Krisztina and Tatay, Tibor, 'Társadalmi Felelősségvállalás A Bankszektorban' (Corporate social responsibility in the banking sector) (2015b) 60 Pénzügyi Szemle/Public Finance Quarterly 96-104.

Lukács, János, Tóth, Márk and Zéman, Zoltán, 'A Számviteli Politika Döntéstámogatásának Modellezése Ágazati Mátrix Fejlesztéssel’ (2012) 22 Gazdaság és társadalom 106-117.

Otten, Toon, Zéman, Zoltán and Gácsi, Roland, 'The Theory Of Bank Controlling' in Zéman, Zoltán (ed) Controller Info Studies (Copy \& Consulting 2014) 217-21.

Rivière, Anne, 'The Future Of Hedge Fund Regulation: A Comparative Approach (United States, United Kingdom, France, Germany, Italy)' (2011) 10 Richmond Journal of Global Law and Business 263-343.

Shadab, Houman B., 'Hedge Fund Governance' (2013) 19 Stanford Journal of Law, Business, and Finance 144-204. 